\title{
Evaluation of folate and vitamin B12 levels in lead exposed workers
}

\author{
Kurşun maruziyeti olan işçilerde folat ve vitamin B12 seviyelerinin değerlendirilmesi
}

\author{
Murat Büyükşekerci ${ }^{1}$, Ceylan Bal' ${ }^{2}$, Mehmet Erdem Alagüney ${ }^{3}$, Erol Rauf A ğıș ${ }^{1}$, Meşide Gündüzöz ${ }^{4}$, \\ Asım Hocaoğlu ${ }^{5}$, Lütfiye Tutkun ${ }^{6}$, Ömer Hınç Yılmaz
}

\section{ABSTRACT}

Objective: Lead $(\mathrm{Pb})$ is a heavy metal and causes dysfunction in hematopoietic, cardiovascular, renal and hepatic systems. The aim of this study is to evaluate the effect of lead exposure on serum vitamin B12 and folate levels.

Methods: 944 patients who were referred to Ankara Occupational Disease Hospital between 2010 and 2014 for periodic examination and whose whole blood lead, serum vitamin B12 and folate levels were assessed are included in this study. 432 patients with whole blood lead levels over $10 \mu \mathrm{g} / \mathrm{dL}$ are defined as exposed group and 512 patients with lead levels below $10 \mu \mathrm{g} / \mathrm{dL}$ are considered as control group. Vitamin B12 and folate levels were compared between two groups. Correlation analysis was also performed.

Results: In the lead exposed group the median folate level was $6.3 \mathrm{ng} / \mathrm{mL}(3.60-17.46)$ and median vitamin B12 level was $310 \mathrm{pg} / \mathrm{mL}(180-854)$ where as folate level was $6.8(3.60-19.67) \mathrm{ng} / \mathrm{mL}$ and median vitamin B12 level was $324 \mathrm{pg} / \mathrm{mL}(190-833)$ in the control group. The difference between two groups was statistically significant ( $p$ value: $<0.001$ for folate and 0.015 for vitamin B12). Lead levels correlated negatively with folate levels ( $r=-0.105$; $p=0.001)$. There was no correlation between lead and vitamin B12 ( $r=-0.061, p=0.062)$.

Conclusion: This study demonstrated that serum folate and vitamin B12 concentrations were negatively associated with lead exposure. It may be important to keep sufficient levels of these micronutrients to prevent possible harmful effects of $\mathrm{Pb}$ exposure regarding hyperhomocysteinemia.

Key words: Lead exposure, vitamin B12, folate

\section{ÖZET}

Amaç: Kurşun ağır bir metal olup, hematopoetik sistem, kardiyovasküler sistem, renal ve hepatik sistemde disfonksiyona neden olur. Bu çalışmanın amacı kurşun maruziyetinin vitamin B12 ve folat seviyesine etkisinin araştırılmasıdır.

Yöntemler: 2010-2014 yılları arasında Ankara Meslek Hastalıkları Hastanesine periyodik muayene amaçlı başvuran tam kan kurşun, serum vitamin B12 ve folat düzeylerine bakılmış 944 kişi çalışmaya dahil edildi. Kurşun se-

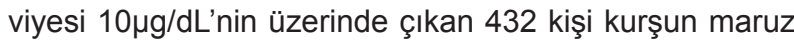
grup, $10 \mu \mathrm{g} / \mathrm{dL}$ 'nin altında çıkan 512 kişi ise kontrol grubu olarak kullanıldı. Vitamin B12 ve folat düzeyleri iki grup arasında karşılaştırıldı. Ayrıca korelasyon analizi yapıldı.

Bulgular: Kurşun maruz grubun median folat seviyesi 6,3 $\mathrm{ng} / \mathrm{mL}(3,60-17,46)$, median vitamin B12 seviyesi ise 310 $\mathrm{pg} / \mathrm{mL}(180-854)$ idi. Kontrol grubunun folat seviyesi 6,8 $(3,60-19,67) \mathrm{ng} / \mathrm{mL}$ median vitamin B12 seviyesi ise 324 $\mathrm{pg} / \mathrm{mL}$ (190-833) idi ( $p$ değerleri; folat için <0,001, vitamin B12 için 0,015). Kurşun düzeyi folat seviyesi ile negatif bir korelasyon gösterirken ( $r=-0.105 ; p=0.001)$, kurşun ve vitamin B12 arasında herhangi bir korelasyon yoktu ( $r=$ $0.061, p=0.062)$.

Sonuç: Bu çalışma folat ve vitamin B12 konsantrasyonu ile kurşun maruziyeti arasında negatif bir ilişki olduğunu gösterdi. Bu durum hiperhomosisteinemi açısından kurşunun olası zararlı etkilerini önlemek için bu vitaminlerin yeterli miktarda alınması açısından önemli olabilir.

Anahtar kelimeler: Kurşun maruziyeti, vitamin B12, folat

${ }^{I}$ Department of Pharmacology, Occupational Diseases Hospital, Ankara, Turkey

2 Department of Biochemistry, Occupational Diseases Hospital, Ankara, Turkey

${ }^{3}$ Department of Internal Medicine, Hacettepe University, Ankara, Turkey

${ }^{4}$ Department of Family Medicine, Occupational Diseases Hospital, Ankara, Turkey

${ }^{5}$ Department of Toxicology, Occupational Diseases Hospital, Ankara, Turkey

${ }^{6}$ Department of Chemical Engineering And Bioengineering Division, Hacettepe University, Ankara, Turkey

${ }^{7}$ Department of Public Health, Ylldirım Beyazıt University, Ankara, Turkey

Yazışma Adresi /Correspondence: Ceylan Bal,

Department of Biochemistry, Occupational Diseases Hospital, Ankara, Turkey Email: ceylandemirbal@gmail.com Geliş Tarihi / Received: 23.06.2015, Kabul Tarihi / Accepted: 12.09.2015

Copyright (C) Dicle Tıp Dergisi 2015, Her hakkı saklıdır / All rights reserved 


\section{INTRODUCTION}

Lead $(\mathrm{Pb})$ is one of the earliest metals discovered by the human race and has been used for over 2000 years. Since $\mathrm{Pb}$ has unique properties such as high malleability, softness, low melting point and resistance to corrosion, it has been used in many different industries like automobiles, paint, ceramics and plastics. The occurrence of free $\mathrm{Pb}$ in biological systems and in the inert environment has increased and this in turn has led to a rise in toxic-biochemical effects on human organism $[1,2]$. Occupational exposure to $\mathrm{Pb}$ may affect different body systems leading to hematopoietic, cardiovascular, renal and hepatic dysfunction. Hemoglobin level and red blood cell count are negatively correlated with $\mathrm{Pb}$ exposure [3] and $\mathrm{Pb}$ may induce nephropathy, proximal tubular damage, glomerular sclerosis [4]. The cardiovascular effects of $\mathrm{Pb}$ includes hypertension, coronary arterial disease, stroke and peripheral arterial diseases [5]. The hepatic enzymes alanine aminotransferase (ALT) and alkaline phosphatase (ALP) rose in workers occupationally exposed to $\mathrm{Pb}[6]$.

Although $\mathrm{Pb}$ is probably one of the most extensively studied heavy metal, the mechanisms underlying the $\mathrm{Pb}$-induced toxicity are complex and these mechanisms have not been thoroughly exhibited yet. The presence of various cellular and molecular mechanisms were reported behind the toxicological manifestations induced by $\mathrm{Pb}$ in the body [2]. The key aspects involved in $\mathrm{Pb}$ neurotoxicity are; oxidative stress, the impairment of neurotransmission, deregulation of cell signaling and membrane bio-physics alterations [7]. Several studies have informed that the activities of antioxidant enzymes, including glutathione peroxidases, catalase and superoxide dismutase were inhibited by $\mathrm{Pb}$. Generation of reactive oxygen species (ROS), stimulation of lipid peroxidation and depletion of antioxidant reserves are accepted as the major contributors to $\mathrm{Pb}$ toxicity [8]. $\mathrm{Pb}$ also has ability to interact and damage DNA though the molecular mechanism of this interaction is not fully understood. Tests for genotoxicity have proved that $\mathrm{Pb}$ compounds induced chromosomal damage, chromosomal aberrations, micronuclei, and increased sister chromatid exchange [9].

Vitamin B12 (cobalamin) and folate are dietary essential vitamins required for human health. Vita- min B12 is a water-soluble vitamin that is stored in the liver and derived from animal products including beef, liver, kidney, chicken, fish, yogurt milk and egg [10]. Vitamin B12 is a cofactor of methionine synthase in the synthesis of methionine, an amino acid that is the precursor of the universal methyl donor S-Adenosylmethionine (SAM). SAM plays a major role in epigenomic regulatory mechanisms. The other metabolic role of vitamin B12 is serving as a cofactor in methylmalonyl coenzymeA mutase in the mitochondrion. This enzyme is the last step in the oxidative degradation of a number of amino acids. Both of mentioned reactions plays a key role in cellular metabolism [11]. Folate is also water soluble B vitamin which presents in human cells as a family of structurally related and also metabolically interconvertable enzyme cofactors those are required for the synthesis of nucleotides, purine and thymidine, and for the synthesis of methionine from homocysteine. Impairment of folate-mediated metabolic pathways may result from B-vitamin deficiencies and/or single nucleotide polymorphisms, and the risk for pathologies such as cancer, cardiovascular diseases and developmental anomalies increases [12].

In this study, we aimed to investigate B12 and folate status in $\mathrm{Pb}$ exposed workers and compare them with control group.

\section{METHODS}

\section{Study population}

In this study, retrospective evaluation of 2379 workers referred to Ankara Occupational Diseases Hospital between 2012 to 2014 for periodic examination was performed .The workers with blood $\mathrm{Pb}$ levels over $10 \mu \mathrm{g} / \mathrm{dL}$ are defined as exposed group $(\mathrm{n}=432)$ and the workers with $\mathrm{Pb}$ levels below $10 \mu \mathrm{g} / \mathrm{dL}$ are considered as control group $(\mathrm{n}=512)$. The exclusion criteria for both groups were history of recent acute or chronic disease and vitamin drug usage. After exclusion, 944 people were included to this study.

\section{Collection of biological samples}

Blood samples were taken from the participants at 'end of workshift'. Blood samples were drawn in 10 $\mathrm{mm}$ tubes with red caps not containing gel (BD Vacutainer) for serum vitamin B12 and folate analyses; 
in $10 \mathrm{~mm}$ EDTA-containing trace elements tubes (BD Vacutainer) for whole blood $\mathrm{Pb}$ analysis. For serum analyses, the specimens were centrifuged at $1500 \mathrm{xg}$ for ten minutes after at least 30 minutes of incubation. All samples were analyzed on the same day.

\section{Analysis methods}

The measurements of serum folate and vitamin B12 were performed using a Chemiluminescent MicroparticleImmunoassay technology on the Architect i2000 analyzer (Abbott, USA). Whole blood $\mathrm{Pb}$ levels were determined using Inductively Coupled Plasma Mass Spectrometry (ICP-MS) (Agilent 7700 series, Tokyo, Japan). Blood samples were digested by the microwave induced acid digestion method. Standard solution of $\mathrm{Pb}$ was prepared by dilution of certified standard solutions (High purity Standards, Charleston, SC, USA). Two level quality control materials (Seronorm, Billingstad, Norway) were used.

\section{Statistical Analysis}

Statistical analysis of data was made by using SPSS (Version 15.0) (SPSS Inc, Chicago, IL, USA) package program. Coherence to normal distribution analysis was made by using Kolmogorov-Smirnov test. Values were presented either as mean plus/ minus standard deviation or as median (minimummaximum), in the case of non-normally distributed data. The presence of a statistically significant difference between the groups in terms of continuous variables was examined with Student's t test for parametric variables and Mann-Whitney U test for non-parametric variables. Spearman's correlation analysis was also performed. All results were accepted statistically significant for $\mathrm{p}<0.05$.

\section{RESULTS}

The demographic and laboratory characteristics of 944 patients who participated in the study are shown in Table 1. Participants were categorized into two groups as control group and $\mathrm{Pb}$ exposed group according to blood $\mathrm{Pb}$ levels $<10 \mu \mathrm{g} / \mathrm{dL}$ and $>10 \mu \mathrm{g} / \mathrm{dL}$ respectively. Variables $\mathrm{Pb}$, vitamin $\mathrm{B} 12$ and folate were non-normally distributed, while age and working duration were normally distributed. No significant difference was observed between groups in terms of age and working duration.

Median folate and vitamin B12 values of exposed group and control group were significantly different ( $\mathrm{p}<0.001$ and $\mathrm{p}=0.015$, respectively) (Figure 1).

\section{FOLIC ACID and VIT B12 LEVELS}

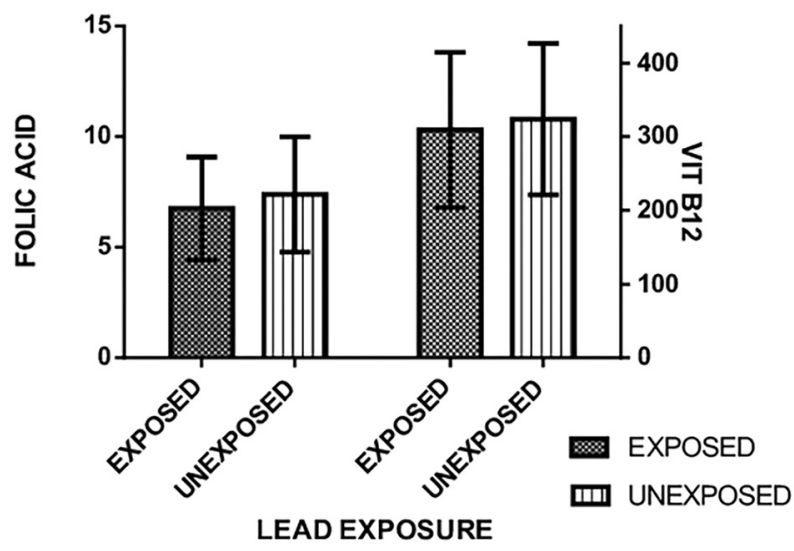

Figure 1. Folic acid and vitamin B12 status of groups (error lines represent \pm standard deviation)

Analysis using Spearman's correlation coefficient showed that whole blood $\mathrm{Pb}$ level correlated negatively with folate levels $(r=-0.105 ; \mathrm{p}=0.001)$. There was no correlation between $\mathrm{Pb}$ and vitamin $\mathrm{B} 12(\mathrm{r}=-0.061, \mathrm{p}=0.062)$.
Table 1. Biochemical parameters and demographic characteristics of groups

\begin{tabular}{lccc}
\hline Parameters & $\begin{array}{c}\text { Control group } \\
(\mathbf{n = 5 1 2})\end{array}$ & $\begin{array}{c}\text { Exposed group } \\
(\mathbf{n = 4 3 2})\end{array}$ & P values \\
\hline Lead $(\mu \mathrm{g} / \mathrm{dL})$ & $2.3(0.01-9.82)$ & $34.15(10.3-116)$ & $<0.001$ \\
Folate $(\mathrm{ng} / \mathrm{mL})$ & $6.8(3.60-19.67)$ & $6.3(3.60-17.46)$ & $<0.001$ \\
Vitamin $\mathrm{B} 12(\mathrm{pg} / \mathrm{mL})$ & $324(190-833)$ & $310(180-854)$ & 0.015 \\
Age (year) & $37.2 \pm 8.3$ & $37.6 \pm 8.6$ & 0.262 \\
Working duration (year) & $14.6 \pm 8.1$ & $18.0 \pm 6.2$ & 0.122 \\
\hline
\end{tabular}

Values are represented as median (Minimum-Maximum) or mean \pm standard deviation 


\section{DISCUSSION}

$\mathrm{Pb}$ accumulates in tissues like bone, brain, kidney and liver when one gets exposed to it. There is not a safe level of $\mathrm{Pb}$ within the human body and the threshold for $\mathrm{Pb}$ level in blood has been updated over the past years. According to the results of various epidemiological studies it is recommended that the blood level of $\mathrm{Pb}$ should be kept below $10 \mu \mathrm{g} /$ $\mathrm{dl}$ [13]. Even exposure to low level of $\mathrm{Pb}$ either occupationally or in environment manner has been shown to induce dysfunction in many target organs. Oxidative stress induced by $\mathrm{Pb}$ is one of the main mechanisms underlying the overt toxicity as seen by an increased prevalence of cardiovascular disease, chronic kidney disease, peripheral arterial disease, diabetes, hyperuricemia or hypertension [14]. Nutrition plays an important role in prevention of $\mathrm{Pb}$ induced toxicity. Certain nutrients like vitamins, mineral elements flavonoids may provide protection against $\mathrm{Pb}$ toxicity hence these nutrients act a pivotal role in restoring the oxidative status in the favor of antioxidant balance [2]. The study objective was to evaluate the effect of occupational $\mathrm{Pb}$ exposure on serum concentrations of folate and vitamin B12.

In our study the median blood $\mathrm{Pb}$ levels of workers were significantly higher than control subjects $34.15 \mu \mathrm{gr} / \mathrm{dl}$ (10.3-116) and 2.3(0.01-9.82) $\mu \mathrm{gr} / \mathrm{dl}$ respectively. The $\mathrm{Pb}$ level in exposed group was similar with that reported by Weaver VM et al [15] but was lower than that reported by Bledsoe ML et all [16]. We found the median blood level of $\mathrm{B} 12$ in $\mathrm{Pb}$ exposed group significantly lower than control group. Also the median blood folate level of $\mathrm{Pb}$ exposed group was significantly lower than control group. Edward $\mathrm{F}$ et al. investigated the relationship between blood $\mathrm{Pb}$, serum folate, red blood cell folate, serum vitamin B12, serum homocysteine and neurobehavioral test performance in adults participating in the third National Health and Nutrition Examination Survey (NHANES 1991-1994). They reported that serum folate, red blood cell folate and serum vitamin $\mathrm{B} 12$ decreased as the blood $\mathrm{Pb}$ concentration increased [17]. Our results were consistent with theirs. However in a study consisting 53 male automotive battery recycling workers, the mean blood $\mathrm{Pb}$ level of $\mathrm{Pb}$ exposed workers were found 24-fold higher compared to controls but it was also reported that these two groups did not dif- fer significantly concerning folate and vitamin B12 levels [18].

Elevated homocysteine is an independent risk factor for ischemic heart diseases [19] and is also a risk factor shared by neurodegenerative conditions such as cognitive decline, Alzheimer's disease and stroke [20]. Though micronutrients such as vitamin B12, folate, vitamin B6 involved in the pathways of homocysteine metabolism it is possible to suggest an interaction between blood $\mathrm{Pb}$ levels and these vitamins on the levels of homocysteine [21]. Bakulski et al. examined the association of $\mathrm{Pb}$ exposure with homocysteine concentrations and the potential modifying effects of dietary intake and plasma concentrations of folate, vitamin B6 and vitamin B12 in a cohort of the Veteran Affairs Normative Aging study with 2301 total participants. They concluded that $\mathrm{Pb}$ exposure was positively associated with plasma homocysteine levels and this association have been found to be stronger among men with below median dietary intake of vitamin B12, vitamin B6 and folate [20].

There are also several experimental studies that investigated the serum vitamin status in $\mathrm{Pb}$ exposure. Tandom et al. showed that the rats exposed to $\mathrm{Pb}$ that were given vitamin $\mathrm{B}$ complex deficient diet had a higher mean blood $\mathrm{Pb}$ concentration than rats exposed to $\mathrm{Pb}$ which were given vitamin $\mathrm{B}$ complex sufficient diet [22]. $\mathrm{Pb}$ and $\mathrm{B}$ vitamins may interact in the bowel and they may also inhibit mutually their absorption.

In conclusion, this study demonstrated that serum folate and vitamin B12 concentrations were negatively associated with $\mathrm{Pb}$ exposure. It may be important to keep sufficient levels of these micronutrients to prevent possible harmful effects of $\mathrm{Pb}$ exposure regarding hyperhomocysteinemia.

\section{REFERENCES}

1. Onunkwor B, Dosumu O, Odukoya OO, et al. Biomarkers of lead exposure in petrol station attendants and auto-mechanics in Abeokuta, Nigeria: effect of 2-week ascorbic acid supplementation. Environ Toxicol Pharmacol 2004;17:169176

2. Flora G, Gupta D, Tiwari A. Toxicity of lead: A review with recent updates Interdiscip Toxicol 2012;5:47-58.

3. Karita K, Yano E, Dakeishi M, et al. Benchmark dose of lead inducing anemia at the workplace. Risk Anal 2005;25:957962 
4. Diamond GL, Risk assessment of nephrotoxic metals. In: Tarloff, J, Lash L, The Toxicology of the Kidney, $3^{\text {rd }}$ edn. London: CRC Press, 2006: 898-927.

5. Solenkova NV, Newman JD, Berger JS, et al. Metalpollutants and cardiovascular disease: mechanisms and consequences of exposure. Am Heart J 2014;168:812-822.

6. Orisakwe OE, Nwachukwu E, Osadolor HB, et al. Liver and kidney function tests amongst paint factory workers in Nkpor, Nigeria. Toxicol Ind Health 2007;23:161-165.

7. Sanders T, Liu Y, Buchner V, et al. Neurotoxic effects and biomarkers of lead exposure: a review. Rev Environ Health 2009;24:15-45.

8. Yedjou CG, Tchounwou CK, Haile S, et al. N-acetyl-cysteine protects against DNA damage associated with lead toxicity in HepG2 cells. Ethn Dis. 2010;20:101-103.

9. Xu J, Lian LJ, Wu C, et al. Lead induces oxidative stress, DNA damage and alteration of p53, Bax and Bcl-2 expressions in mice. Food Chem Toxicol. 2008;46:1488-1494.

10. Anyanwu EC, Kanu I. Biochemical impedance on intracellular functions of vitamin B12 in chronic toxigenic mold exposures. ScientificWorldJournal 2007;7:1649-1657.

11. Guéant JL, Caillerez-Fofou M, Battaglia-Hsu S, et al. Molecular and cellular effects of vitamin B12 in brain, myocardium and liver through its role as co-factor of methionine synthase. Biochimie. 2013;95:1033-1040.

12. Stover PJ. Physiology of folate and vitamin B12 in health and disease. Nutr Rev. 2004;62:3-12.

13. Yakub M, Iqbal MP. Association of blood lead $(\mathrm{Pb})$ and plasma homocysteine: a cross sectional survey in Karachi, Pakistan. PLoS One. 2010;5:e11706.

14. Sirivarasai J, Kaojarern S, Chanprasertyothin S, et al. Environmental Lead Exposure, Catalase Gene, and Markers of
Antioxidant and Oxidative Stress Relation to Hypertension: An Analysis Based on the EGAT Study. Biomed Res Int. 2015;2015:856319.

15. Weaver VM, Kim NS, Jaar BG, et al. Associations of lowlevel urine cadmium with kidney function in lead workers. Occup Environ Med 2011;68:250-256.

16. Bledsoe ML, Pinkerton LE, Silver S, et al. Thyroxine and free thyroxine levels in workers occupationally exposed to inorganic lead. Environ Health Insights 2011;5:55-61.

17. Krieg EF Jr, Butler MA. Blood lead, serum homocysteine, and neurobehavioral test performance in the third National Health and Nutrition Examination Survey. Neurotoxicology 2009;30:281-289.

18. Minozzo R, Deimling LI, Santos-Mello R.Cytokinesisblocked micronucleus cytome and comet assays in peripheral blood lymphocytes of workers exposed to lead considering folate and vitamin B12 status. Mutat Res 2010;697:24-32.

19. Homocysteine Studies Collaboration. Homocysteine and risk of ischemic heart disease and stroke: a meta-analysis. JAMA 2002;288:2015-2022.

20. Bakulski KM, Park SK, Weisskopf MG, et al. Lead exposure, B vitamins, and plasma homocysteine in men 55 years of age and older: the VA Normative Aging Study. Environ Health Perspect 2014;122:1066-1074.

21. Lee YM, Lee MK, Bae SG, et al. Association of homocysteine levels with blood lead levels and micronutrients in the US general population. J Prev Med Public Health 2012;45:387-393.

22. Tandon SK, Flora SJ, Singh S. Influence of vitamin B-complex deficiency on lead intoxication in young rats. Indian J Med Res 1984;80:444-448. 